\title{
Digital Literacy With EFL Student Teachers: Exploring Indonesian Student Teachers' Initial Perception About Integrating Digital Technologies Into a Teaching Unit
}

Tati Lathipatud Durriyah*, Muhammad Zuhdi

Fakultas Ilmu Tarbiyah dan Keguruan, Universitas Islam Negeri Syarif Hidayatullah Jakarta, Indonesia

Corresponding author: Tati Lathipatud Durriyah, E-mail: tati.wardi@uinjkt.ac.id

\section{ARTICLE INFO}

Article history

Received: January 30, 2018

Accepted: July 21, 2018

Published: July 31, 2018

Volume: 6 Issue: 3

Conflicts of interest: None

Funding: None

\begin{abstract}
Research found that many student teachers are active users of digital technologies yet they are reluctant to make use of digital technologies for literacy teaching purposes. Efforts to prepare student teachers for technology integration are pressingly needed. Also needed is data that informs us about student teachers' participation (engagement) with digital technologies and how they might utilize those technologies for literacy teaching. The article reports on a classroom research project that explored Indonesian student teachers' initial perception about the use of digital technologies for EFL teaching. For one semester, the first author taught a course to a group of student teachers at a state Islamic university in Jakarta in which they learned conceptual and practical knowledge about digital technologies in teaching and learning. The student teachers were tasked to explore digital technologies available and had to integrate those technologies into teaching units contained in a junior high English textbook. Popular digital technologies selected included Facebook, blogs, Skype, and WhatsApp. Each offers unique potential to facilitate and enhance language learning. Student reflections provided insight into their considerations for their digital technology selections.
\end{abstract}

Key words: Digital Literacy, Qualitative, Student Teachers, EFL, Indonesia

\section{INTRODUCTION}

Acquiring literacy is fundamental for one's development. People whose literacy skills are developed are more likely to explore and reach their potential (UNESCO, 2006). The International Literacy Association (ILA), an authoritative world literacy organization, publishes on their website a definition of literacy:

Literacy is the ability to identify, understand, interpret, create, compute, and communicate using visual, audible, and digital materials across disciplines and in any context. The ability to read, write, and communicate connects people to one another and empowers them to achieve things they never thought possible (para.1)

The statement highlights two important points. First, the literacy teaching currently needed should enable people to communicate and connect. Second, people currently use various modes of communication including text, audio, graphics, and video. This literacy definition encompasses literacy engagement - also an aspect of digital literacy as students engage with digital contexts (e.g., digital technologies). Literacy engagement here is understood to be the manner in which students engage in learning (participate) using those contexts (Hafner, Chik, \& Jones, 2015). It is clear, then, that teaching literacy skills that enable people to communicate and connect through such modes is a key that drives current literacy education.
Indonesian students' literacy skills are unfortunately not well developed. USAID (2008) reported that many Indonesian K-12 students displayed low critical thinking abilitythey lacked the ability to reflect and evaluate information presented to them. This ability is paramount for students to be academically and professionally advanced (Spires \& Bartlett, 2012). Spires and Bartlett contend that in an increasingly digital environment, students must acquire digital literacy skills that enable them to select and use digital tools that are suitable for their purposes. Echoing ILA, Spires and Bartlett view digital literacy as "a wide-ranging set of practices that enable students to create, share, and understand meaning and knowledge" in a digital environment $(2012$, p. 6).

According to ILA's 2018 report, digital literacy tops the list as the most prescient topic to be addressed in literacy education. The report surveyed and interviewed researchers and literacy educators from around the world. The report also noted that there should be more attention given to strategic efforts for excellent literacy education. One of those efforts involves teacher preparation that equips student teachers with skills to foster students' literacy development. Specifically one that is concerned with digital technology.

To our knowledge, studies that attempted to investigate Indonesian student teachers' use of digital technology for teaching and learning are small in number, and they tend to 
be quite specific in terms of the use of digital technologies (e.g., Rodliyah, 2016). Our research is explorative in the sense that we asked student teachers about their preferred digital technologies when planning to teach. We claim that there is a large gap between the available research and our need to be informed about digital technology use among student teachers.

\section{Objectives and Research Questions}

In this research, we sought to address a question related to the digital technology use within a teacher education program. We were interested in investigating the learning experiences of student teachers enrolled in a course titled Media and Language Learning. The course goal was to educate student teachers about teaching a subject (English) that is informed by digital literacy. Specifically, our research aimed to investigate the student teachers' perception about the use of digital technologies as they learned about theories and practices related to the use of digital technologies in teaching and learning. Our guiding questions were:

1. What kind of digital technologies would student teachers select to integrate into their teaching plan?

2. What were their considerations when selecting digital technologies for teaching and learning?

\section{Digital Literacy and Teacher Education}

Research on digital literacy is well documented (e.g., Coiro, et al., 2008). Recent developments have provided us with information about some digital literacy roles in literacy education. Major reports such as the Cambridge Assessment Report summarized several conclusions concerning digital literacy in literacy education. First, literacy education should encompass the teaching of print, media literacy, and digital technology. Second, literature is at the core of literacy teaching, and it should be taught within the context of digital discourse (Cambridge Assessment, 2013). These conclusions emphasize that digital literacy is a vitally important skill that students in the digital age should acquire.

What counts as digital literacy? Spires and Bartlett (2012) simplify the scope of digital literacy into three categories: finding and utilizing digital content, producing digital content, and disseminating digital content. These categories highlight complex skills and abilities that students must obtain. Skills such as critical thought and value judgment are very important for locating and utilizing digital content. Likewise, creativity, innovation, and understanding of sociological context are very critical for producing and disseminating digital contents.

A number of studies have explored digital literacy in the context of teacher education. Price-Dennis (2016) and Price-Dennis and colleagues (2014) investigated some efforts to prepare student teachers to integrate technology into literacy teaching. Their findings reveal a gap between the availability and use of digital technologies in classrooms. The sentiment is shared by literacy researchers with similar interests (Bauer \& Kenton, 2005; Doering, Hughes, \& Huffman, 2003; Koc \& Bakir, 2010; Lei, 2009; Wright \& Wilson,
2011). This gap in technology use is concerning when considering that technology is available and a part of students' daily lives. Additionally, a lack of accommodation of digital technologies use in a teacher education program will not help student teachers to imagine how a pedagogy that involves digital technologies can be structured and implemented in an established learning environment (classrooms). Although limited in number, available research notably demonstrates that student teachers tend to be more sensitive to the use of digital technologies when they are accustomed to and are active users of the digital technologies (Collier, Foley, Moguel \& Barnard, 2013; Hundley \& Holbrook, 2013; Williams \& Baumann, 2008). We may conclude that what is pressing in promoting digital technologies in teacher education is the effort to instruct student teachers to learn "about, through, and with technology" (Cervetti, Damico, \& Pearson, 2006, p. 383), including instruction on how to be active participant in digital literacy practices (Hundley \& Holbrook, 2013). Meanwhile, other studies also present us with the possibility of managing an online learning environment (Juzwik et al., 2012) and its relation to promoting student teachers' confidence in writing skill (Norman \& Spencer, 2005).

To summarize, the aforementioned research has informed us that it is crucial for teachers to be active users of digital technologies in order to benefit from them. Included in those benefits is the use of digital technologies within a learning environment that enables student teachers to increase their confidence in literacy skill learning.

\section{METHODS}

\section{Context and Participants}

Our research utilized a qualitative paradigm and took place within an undergraduate English education program at a state affiliated Islamic university in Jakarta. For one semester, the first author taught a course called Media and Language Learning. The 35 enrolled student research participants could be described as active users of leading social media platforms. For instance, a quick survey conducted at the beginning of the course showed that all student teacher participants had Facebook accounts and were actively logged in. All of them owned digital technology devices such as laptops and smartphones, enabling them to access digital information and data using a wireless network.

\section{The Course and Data Sources}

The course content encompassed basic discussions of technology in teaching, different kinds of technology, and digital literacy and its teaching application. The course aimed to promote development of Indonesian student teachers' digital literacy. In order to do that, course goals emphasized building the student teachers' conceptual and practical knowledge about teaching English through the use of modern technology. To facilitate this process, the student teachers were assigned the text Teaching English Language Learners Through Technology by Erben, Ban, and Castañeda (2009). Each week they took turns leading the book 
discussion. Selected chapters from Dudeney, Hockly, and Pegrum's (2013) Digital Literacies were also assigned and discussed to broaden the perspective about technology use in teaching that would include digital literacy, especially the idea of creating and sharing digital contents. The course assignments were directly tied to the use of media technology for language learning. They included writing weekly reflective papers on the readings and classroom discussions. The student teachers were assigned to expand teaching units by integrating digital technologies relevant to each unit. Working in groups, they used a grade seven English textbook (an official Kurikulum 2013 textbook) to exercise their working understanding about technology and learning by way of infusing relevant technologies into units of teaching contained in the textbook. The students were encouraged to explore available and familiar technology and to make sense of how those technologies might be beneficial for learning. All of these assignments were submitted to the instructor in both paper and electronic copies. The copies become the data sources for this research.

\section{Digital Literacy Focus}

Digital literacy in relation to the teaching of English in this research focused on the integration of digital technologies into language teaching (Dudeney et al., 2013; Hockly, 2013). In Hockly's work entitled Digital Literacies: What are They and Why Should We Care?, Hockly argues that it is imperative for language teachers to teach media literacy skills and digital competencies (digital literacy or an "ability to effectively make use of the technologies at our disposal" (2013, para. 2). Beyond simply gaining practical technical skills, Hockly asserts that digital literacy in EFL teaching will enable students to use and create digital products and connect to wider audiences of fellow digital readers and writers.

\section{Data Analysis}

To analyze our data, we followed a tradition of Grounded Theory which enabled us to approach data organically and minimize certain theoretical assumptions. We used Grounded Theory's general principles as put forward by Strauss and Corbin (Glesne, 2006) of re-reading the data sources for the identification of themes, re-analyzing the data by continuously comparing themes across data (constant comparative method), and then using open coding to identify themes and patterns of data.

Overall, this process included four phases: first, comparing results with emerging themes; second, testing and redefining the themes; third, continuing to reduce the number of themes; and fourth, constructing explanatory theory position data.

In the first phase, we categorized our coding following a wide range of themes, including the four language skills (listening, reading, speaking, and writing) and vocabulary teaching. Second, as we coded we learned that a number of digital technologies were frequently found across the themes. For instance, Facebook was found in the themes of writing, reading, and vocabulary teaching. We also collapsed the initial themes that separated technologies being used as a tool for instruction and being used for learning activities; instead, we focused on describing activities that student teachers performed with digital technologies. Therefore, as a result of reduction in the third phase, we focused on the themes that specified explicitly the kinds of digital technologies that student teachers preferred in the activities within their lessons. Finally, we connected the themes with theoretical justification. For instance, in explaining the student teachers' preference for learning in a Facebook closed group space (they used it as an electronic classroom that allows anyone to engage in active participation), we referred to a theory that highlights the importance of providing language learners with many opportunities/spaces to use their language productively and meaningfully (Erben et al., 2009).

In every phase of data collection and analysis, our goal was the data would present us literacy teaching that emerged from data sources collected from research participants. Specifically, we focused on digital literacy put forward earlier by Hockley that entails the "ability to effectively make use of the technologies at our disposal" (2013, para. 2). We wanted to know which of many accessible teaching technologies the student teachers preferred as shown within their lesson plans.

We then narrated the final themes while guided by these research questions: What kind of digital technologies would student teachers select to integrate into their teaching plan? and What were their considerations when selecting digital technologies for teaching and learning?

\section{RESULTS}

The main themes that we highlighted from our data involved digital technology use for teaching. More specifically, our data suggest that the digital technologies appeared to have great potential for teaching English language skills. In showing the findings, we discuss the amounts of data that correspond to digital technologies being selected-answering the question: What kind of digital technologies would student teachers select to integrate into their teaching plan? Embedded in the discussion are student teachers' considerations for selecting those technologies, answering the question: What were their considerations when selecting digital technologies for teaching and learning? Our findings discussion will follow the following order: Facebook closed groups, blogs, Skype (and other VoIPs), and WhatsApp.

\section{Facebook Closed Group}

Of all the features in Facebook, a Facebook closed group was the student teachers' most preferred digital technology. Creating a closed group is the first step to transform Facebook into a space for teaching and learning activities. Many student teachers in this research claimed that a Facebook closed group is an ideal place to facilitate e-classrooms as the platform enables students to have interactive discussions.

According to our student teachers, a Facebook closed group offers experiences found in typical online classrooms (online class environment). They are free to 'post' from a 
wide variety of digital formats such as videos and news links. They can invite others for discussion in the 'comment' section. Similar to a regular class, students in a Facebook group can conveniently perform activities such as getting information from students, disseminating information, and reviewing books with ease. Students just need to copy a link and share it to a group wall. Images, videos, and video links from Youtube can all be posted, and all of these can be used for classroom discussion. Students can also post an electronic document, for example, as part of a class assignment submission; they can submit their assignments by uploading electronic copies onto a group wall. They would then 'tag' the teacher to notify him or her that the assignment has been submitted. Similarly, teachers can also tag any students whose assignments have not been submitted. Many student teachers found this seemingly transparent process exciting and motivating. For one, they are able to read classmates' work. Furthermore, they enjoyed participating in the Facebook group since it opened wide opportunities for students to comment and to give 'likes' (a thumbs-up icon). They argued that teachers will benefit from having opportunities available to provide additional teaching resources beyond the textbook by sharing digital content to a Facebook group wall. A student teacher succinctly stated these aforementioned potential benefits of a Facebook closed group as follows: "Facebook closed group as an online platform can be used as a place to share materials, discussions between teachers, students (and colleagues), collect assignments, and other activities."

The student teachers felt that a Facebook group's most useful feature lies in its ability to provide a space for interactive discussion. One type of interactive discussion they planned to do in a Facebook group would look like the following: the teacher writes on a group wall questions related to a song and students then comment on these questions (the song should have been played earlier in classroom). In another case, the teacher uploads a set of images with different expressions which then students will comment on with narrative descriptions for each one of those images. Other interactive discussions may occur when students exchange comments or give feedback on assignments that their classmates upload on the group wall. Students will gain benefits from both exercising their writing skills as well as learning from classmates. For teachers, activities such as these will allow them to monitor students' writing skill development.

Continuing the example activity above, student teachers in this study planned an activity involving writing a description about a range of different expressions. They would then ask specifically for students to write a descriptive piece using adjectives. Other students would have a chance to comment on each adjectival description and state which one they found well written. Student teachers felt that this peer commenting and 'liking' would motivate their students to do their best in order to earn positive feedback. In short, student teachers in this study appeared to be convinced that a Facebook group is a good space for interactive activities. Similarly, the student teachers suggested that the use of a Facebook group to enhance student learning could be maximized. Most specifically, they planned to use online groups to extend the limited hours of classroom instruction. In their teaching plan, they assigned after school online work to maintain the interactive discussion about topics yet to be mastered/comprehended by students.

Student teachers also expressed feeling less intimidated within the Facebook group, and they felt this more comfortable space increased their potential for learning. They reflected on their own experiences as active Facebook users and noted that they could express their opinions more freely there than in a typical classroom. As one student teacher remarked, "We prefer Facebook because in here students tend to be active and free to express an opinion when asked by teachers." Many confessed that they often feel too embarrassed or intimidated to share opinions in class. One student teacher claimed that "Facebook has an ability to encourage students so that they feel comfortable to express opinions without fearing of making mistakes."

\section{Blogs}

Blogs (weblogs or online journals) were quite popular among student teachers. Many maintained a blog and wrote regularly about a variety of topics that interested them. They seemed to nurture their writing habit on a blog, so it is not surprising that a blog's potential for writing skill development appeared obvious for many of them. Creating a blog involves establishing an account with a blogging platform. Many student teachers mentioned Blogspot.com, Wordpress. com, and Wattpad as popular sites in Indonesia. Some of the writing-related activities they planned to do included exploring different genres of writing. Student teachers discussed having their students study the descriptive writing genre by writing about their favorite singers. Other genre writing such as poetry could be based upon a theme of their choice such as parents, friends, and teachers. Student teachers also planned to ask students to complete an interactive dialogue activity on a blog. First students would write a dialogue from a picture depicting settings, characters, or an activity). They would then write their version of dialogue on their own blog. Later, students would visit their classmates' blogs and leave comments, suggestions, and perhaps alternative dialogues. The students could use classmates' feedback and comments to revise their writing. Another interactive writing idea was to have students develop a letter for correspondence to a classmate (letter writing). Unlike the previous activity, students would publish a revised letter on their blog. They would address it to a classmate whom they intend to become a letter recipient.

Student teachers also proposed a blog activity for reading and writing connection (Lee, 2015). The planned teaching process would begin with students responding to a reading. Through the written summarizing or retelling, student comprehension would be apparent, and their writing progress within the blog posts would be evident. Their gradual writing process would be documented on the blog from beginning to final draft. In this case, documenting their writing process on a blog would enable students to have a firsthand experience of writing as a process and give them control and responsibility for their writing process (a sense of writing ownership). 
Including blogs in their teaching plans may seem natural as the student teachers have already used blogs to write and document their thoughts and feelings. When blogging, they include hashtags (defined by Merriam-Webster web dictionary as "a word or phrase preceded by the symbol \# that classifies or categorizes the accompanying text"). Incorporating hashtags within these digital platforms such as Wattpad gives them a sense of connection to others who have similar interests. Clicking on hashtags takes them to other blogs where they are able to learn and be inspired by other people's writing. Having a personal space through a blog and at the same time wanting to connect with others seemed to dominate the student teachers' preference to integrate blog technology into a teaching plan.

\section{Skype}

Skype and other similar VoIPs (Voice over Internet Protocol), a digital technology used for live verbal communication via the Internet, is popular in Indonesia. The student teachers in this study identified Skype's potential for learning, especially as a tool to exercise students' oral English proficiency (Erben et al., 2009). Categorized as synchronous technology, Skype needs an Internet connection to function. An ideal use of Skype for learning is an activity that happens in real-time (live) where being spontaneous is part of the learning process, as with speaking skills. The student teachers felt Skype would work well as a tool for oral English proficiency practice with peers. Using a Skype-installed smartphone that connects to the Internet, students would be able to conveniently practice with partners. One student, a regular user of Skype and similar VoIPs, cited the popularity of Skype and its potential for learning when endorsing the practice: "For teaching speaking skill, I suggest Skype and Google hangouts since these two are commonly used in Indonesia. When I was in high school my friend and I often used Skype and Google hangouts for video call. I think they are also suitable for teacher to use the tools both as training and assessing speaking skill."

Skype is also commonly used for conferencing. The student teachers preferred Skype technology for its ease of installation on personal technology devices like laptops and smartphones. In addition to its clear voice quality, they argued that Skype has features that enable them to have a conference in a group (group conference).

\section{WhatsApp}

An instant messaging platform, WhatsApp's popularity is credited to its affordability, immediacy, flexibility of space (could contain a long text), and a sense of community (Church \& Oliveira, 2013). These factors about WhatsApp were confirmed in the present study as student teachers explained how they planned to take advantage of using WhatsApp for teaching and learning purposes. First, they referred to a 'group' feature in WhatsApp that allows them to communicate and disseminate information to invited members (typically created exclusively for a range of different interests). A WhatsApp group makes it possible for members to distribute documents, video clips, photos, and links to other sites or information, and even to broadcast news to much wider audiences. The following quote is from a student teacher describing how she planned to infuse WhatsApp into a classroom activity.

A teacher asks students to go out classroom to find a room similar to the description in the book or that have been discussed. Students will take a note what they will be findings. Working in a group, they are free to look for a room with a suitable description. During the searching time, the teacher and students will be connected via WhatsApp in one of their digital devices (smartphone or Ipad). Using WhatsApp students will share what they have found (images and description). After the time is up and images being searched are collected, students will write a description about each one of the pictures.

The use of WhatsApp in the above activity is not only as an immediate communication tool during a dynamic group activity, but also as a detailed and transparent process during the time students are configuring their understanding (learners' community).

Student teachers enjoyed WhatsApp for its intimacy and for the communal experience. They maintained that they formed a sense of community when they were in a WhatsApp group. This sense of community and intimacy within WhatsApp differed from their Facebook group experience where they felt less privacy. However, the student teachers agreed that WhatsApp carries some limitations for learning - more so than other technologies like Facebook, for instance. In WhatsApp, users have to download videos within messages in order to watch them; this is not the case with Facebook where users can watch videos instantly from the Facebook page. Student teachers also found WhatsApp message threads somewhat overwhelming and hard to follow. They were skeptical about using WhatsApp for classroom discussion and considered a Facebook group to be more preferable and conducive for learning.

\section{DISCUSSIONS}

This research sought to explore Indonesian student teachers' initial perceptions about digital technologies for teaching and learning. Our report focused on digital technologies that they selected to include in their teaching plans as well as their ideas for including them. When selecting those digital technologies, the student teachers referred to their personal experiences when explaining what made these technologies potential tools for teaching and learning. In other words, these digital technologies emerged organically among these research participants. For discussions, we will focus on connecting the findings with research about potential digital technologies that confirms our exploratory research findings. We intend to show that the potential of the student teacher selected digital technologies has also been found in other research contexts and approaches beyond the present study.

The student teachers' inclusion of Facebook in their teaching plans reveals information that echoes the analysis advanced by Manca and Ranieri (2013), two Italian scholars who conducted a meta-review analysis on the use of 
Facebook for learning. We will use their review as a reference in discussing our Facebook findings. (a) Facilitating e-classrooms. Our findings confirmed Manca and Ranieri's review on studies about the way in which a Facebook group and some of its identifiable characteristics are useful as a learning space. The characteristics that they identified include being able to share learning resources, to leave comments, to write on walls, and to initiate discussions. The fact that a Facebook group provided features such as these deems it a good space for learning. (b) Having interactive discussion. To some extent, this finding echoes Manca and Ranieri's conclusion that a Facebook group's use for learning is overwhelmingly for interactive discussions. Furthermore, they have an interesting finding that in having an interactive discussion in a Facebook group, students appear to benefit from learning from each other (mutual learning), which makes them more aware of exercising critical thinking. (c) Providing a safe and less intimidating space. This confirms Manca and Ranieri's research review which concludes that Facebook is one digital technology that is able to provide supports and facilities to learn as while on Facebook, students tend to freely participate, discuss, and share information. They also tend to be more open to discussion. Additionally, in some cases, English language learners participated and interacted more online than in traditional classrooms where they tend to be passive due to language barriers and social pressures.

Our blog findings, especially when pertaining to the student teachers' suggestion that they had more sense of ownership, echo the research finding by Ducate and Lomicka (2008). Ducate and Lomicka's research showed that a blog appears to be helpful skill practice for students who are learning to write in a foreign language. Their findings about the advantages of writing on a blog are especially evident in providing learners a strong sense of belonging and writing creativity (ownership and creativity). Ducate and Lomicka also point to other benefits of blogs for students; students appear to be comfortable on their blog experimenting with language use, a crucial factor in mastering a new language. In short, writing on a blog gave students a space where they felt more relaxed in experimenting and exercising expressions while learning a foreign language. At the same time, though, a blog is by default a public space (unless the setting is changed to private). In this case, a foreign language learner who feels comfortable writing on a blog is somewhat connected to teachers and classmates who are able to leave comments and offer suggestions. This finding is similar to the present study about including tags (hashtags) in a blog posting in order to connect with others who share interests.

The student teachers in the study noted Skype's potential benefit for developing students' verbal ability —as in this case, oral English proficiency. A question whether Skype presents itself as beneficial for language learning was examined in an experimental research by Japanese researchers Kato, Spring, and Maori (2016) where they assigned control and experimental groups of students who learned foreign languages (English and Japanese). The researchers used Skype as a support to provide a meaningful experience in an authentic environment. In using Skype, both groups had native partners in respective language (American students with Japanese native partners and Japanese with American partners) with whom they practiced using structures and activities developed by the researchers. Their findings showed statistically significant improvement of communication skills (listening and speaking skills) in both groups of language learning students. When they communicated, they tended to talk longer and were able to respond to the target language being spoken. Especially with American students studying Japanese, the improvement showed in their ability to speak with more varied vocabularies and longer sentences. In contrast, control students of both language groups who received no Skype practices showed little improvement. Also, their qualitative findings explanation is quite convincing in affirming the benefits of using Skype as a medium for language learning development.

This study's student teachers appreciated WhatsApp's ability to offer a sense of immediacy and intimacy in a learning activity. To some extent, WhatsApp serves as a window that gives us insights about the student teachers' personal agency in the learning process as well as insights about their social interactions and collaborations with others (Dabbagh \& Kitsantas, 2012). This is perhaps what British researchers O'Hara and colleagues (2014) called a process of 'doings' in WhatsApp where members build connections by sharing brief notes and short narrations and sharing light moments by communicating thoughts, feelings, news, photos, videos, and links. O'Harra and colleagues contend that the use of WhatsApp for such activities fits the description of a 'dwelling' place in which WhatsApp is a digital platform where people/members enjoy being involved in dynamic discussions that cover a wide range of topics and interests - "dwelling is not simply a place but a 'doing' and needs to be seen as constituted by things done and felt endlessly in the moment-by-moment of togetherness and directionality" (p. 11).

\section{CONCLUSIONS}

Earlier we cited English teaching specialist Nicky Hockly (2013) who insisted that English teachers should incorporate digital literacy, competency in digital technologies use, into teaching. Our semester long data revealed insights pointing to a number of advantages as perceived by the Indonesian EFL student teachers. The student teachers in this research agreed that digital technologies like a Facebook closed group offer inviting environments for students to participate; students feel safe to share thoughts in a Facebook closed group. Classrooms that integrate digital technologies have a good chance to foster students' ownership in developing writing skill (blogs) and to develop spontaneous and authentic oral communication (Skype). Finally, student teachers felt that the ability of messaging platforms like WhatsApp to offer intimacy and immediacy provides the potential to nurture a dynamic community of learners where feelings of togetherness and accessibility are expected. As the authors' final note, the digital technologies mentioned above are categorized as synchronous - technology requiring users to be "online at the 
same time in order to communicate in real time" (Erben et al., 2009 , p. 84). This online connectivity requirement may be an issue for students in Indonesia who like the student teachers in this research would likely be dependent on the free wireless network available on a school/university campus. Otherwise, they would have to ration their use of limited Internet data from smartphones. We are suggesting this as a point of consideration for teachers who are interested in exploring digital technology integration into their teaching. Finally, the present study limits its discussion on student teachers' engagement with digital technologies for teaching. Therefore, we decided that concerns related to data privacy and online security were beyond the scope of the current discussion.

\section{ACKNOWLEDGEMENTS}

The research for this paper was supported by Pusat Penelitian dan Penerbitan (Puslitpen) Universitas Islam Negeri Jakarta.

\section{REFERENCES}

Bauer, J., \& Kenton, J. (2005). Toward technology integration in the schools: Why it isn't happening. Journal of Technology and Teacher Education, 13(4), 519-546.

Cambridge Assessment. (2013). What is literacy? An investigation into definitions of English as a subject and the relationship between English, literacy and 'being literate.' A Research Report Commissioned by Cambridge Assessment.

Cervetti, G., Damico, J., \& Pearson, P. D. (2006). Multiple literacies, new literacies, and teacher education. Theory into Practice, 45(4), 378-386.

Church, K. \& de Oliveira, R. (2013). What's up with WhatsApp? Comparing mobile instant messaging behaviors with traditional SMS. Mobile HCI 2013-Collaboration and Communication. Retrieved from https:// pdfs.semanticscholar.org/3ea1/9dcbe 7 c 8 fcde $728 f-$ 546d96543ae9e2aa8d07.pdf

Coiro, J., Knobel, M., Lankshear, C., \& Leu, D. J. (2008). Handbook of research on new literacies. New York: Lawrence Erlbaum Associates.

Collier, S., Foley, B., Moguel, D., \& Barnard, I. (2013). Write for your life: Developing digital literacies and writing pedagogy in teacher education. Contemporary Issues in Technology and Teacher Education, 13(3), 262-284.

Dabbagh, N., \& Kitsantas, A. (2012). Personal Learning Environments, social media, and self-regulated learning: A natural formula for connecting formal and informal learning. Internet and Higher Education, 15(1), 3-8.

Doering, A., Hughes, J., \& Huffman, D. (2003). Pre-service teachers: Are we thinking with technology? Journal of Research on Technology in Education, 35(3), 342-362.

Ducate, L., \& Lomicka, L. (2008). Adventures in the blogosphere: From blog readers to blog writers. Computer Assisted Language Learning, 21(1), 9-28.

Dudeney, G., Hockly, N., \& Pegrum, M. (2013). Digital literacies. Harlow: Pearson

Erben, T., Ban, R., \& Castañeda, M. E. (2009). Teaching English language learners through technology. New York: Routledge.
Glesne, C. (2006). Becoming qualitative researchers: An introduction. Boston: Pearson Education Press.

Hafner, C. A., Chik, A., \& Jones, R. H. (2015). Digital literacies and language learning. Language Learning \& Technology, 19(3), 1-7. Retrieved from http://lit.msu. edu/issues/october2015/commentary.pdf

Hashtag. 2018. In Merriam-Webster.com. Retrieved March 29, 2018, from https://www.merriam-webster.com/dictionary

Hockly, N. (2013, 29 April). Digital literacies: What are they and why should we care? Retrieved from https://www. teachingenglish.org.uk/article/digital-literacies-whatare-they-why-should-we-care

Hundley, M., \& Holbrook, T. (2013). Set in stone or set in motion?: Multimodal and digital writing with pre-service English teachers. Journal of Adolescent \& Adult Literacy, 56(6), 500-509.

International Literacy Association. (2018) What's hot in literacy: 2018 report. Retrieved from https://www.literacyworldwide.org/docs/default-source/resource-documents/whats-hot-2018-report.pdf

International Literacy Association. (2016) Why literacy? Retrieved from http://www.literacyworldwide.org/why-literacy

Juzwik, M. M., Sherry, M. B., Caughlan, S., Heintz, A., Borsheim-Black, C., Auerbach, S., \& Herbst, P. (2012). Supporting dialogically organized instruction in an English teacher preparation program: A video-based, Web 2.0-mediated response and revision pedagogy. Teachers College Record, 114(3), 1-42.

Kato, F., Spring, R., \& Mori, C. (2016). Mutually benefinical foreign language learning: Creating meaningful interactions through video-synchronous computer mediated communication. Foreign Language Annals, 49(2). 355-366.

Koc, M., \& Bakir, N. (2010). A needs assessment survey to investigate pre-service teachers' knowledge, experiences and perceptions about preparation to using educational technologies. The Turkish Online Journal of Educational Technology, 9(1), 13-22.

Lee, S. (2015). Joining the 'literacy club': When reading meets blogging. ELT Journal, 69(4), 373-382.

Lei, J. (2009). Digital natives as pre-service teachers: What technology preparation is needed. Journal of Computing in Teacher Education, 25(3), 87-97.

Manca, S., \& Ranieri, M. (2013). Is it a tool suitable for learning? A critical review of the literature on Facebook as a technology-enhanced learning environment. Journal of Computer Assisted Learning, 29(6), 487-504.

Norman, K.A., \& Spencer, B.H. (2005). Our lives as writers: Examining preservice teachers' experiences and beliefs about the nature of writing and writing instruction. Teacher Education Quarterly, 32(1), 25-40.

O’Hara, K., Massimi, M., Harper, R., Rubens. S., \& Morris, J. (2014). Everyday dwelling With WhatsApp. Retrieved from https://www.microsoft.com/en-us/research/wpcontent/uploads/2014/03/WhatsAppCSCW2014paper. pdf 
Price-Dennis, D. (2016). Developing curriculum to support black girls' literacies in digital spaces. English Education, 48(4), 337-360.

Price-Dennis, D., Wiebe, M. T., \& Fowler-Amato, M. (2014). Learning to develop a culturally relevant approach to $21^{\text {st }}$ century writing instruction. Teaching/Writing: The Journal of Writing Teacher Education, 3(2). Retrieved from http://scholarworks.wmich.edu/wte/vol3/iss2/5

Rodliyah, R. S. (2016). Using a Facebook closed group to improve EFL students' writing. TEFLIN Journal, 27(1), 82-99.

Spires, H. A., \& Bartlett, M.E. (2012) Digital Literacies and Learning: Designing a Path Forward. The William \& Ida Friday Institute, North Carolina State University.

UNESCO Report. (2006). Indonesian Ministry of Education. Paper commissioned for the EFA Global Monitoring Re- port 2006, Literacy for Life. Retrieved from http://unesdoc.unesco.org/images/0014/001416/141639e.pdf

USAID (2008). A partnership for prosperity, USAID strategy Indonesian 2009-2014 (2008). Retrieved from https:// www.ircwash.org/sites/default/files/USAID-2010-Partnership.pdf

Williams, T. L., \& Baumann, J. F. (2008). Contemporary research on effective elementary literacy teachers. In Y. Kim, V. J. Risko, D. L. Compton, D. K. Dickinson, M. K. Hundley, R. T. Jimenez, K. M. Leander, \& D. W. Rowe (Eds.), $57^{\text {th }}$ yearbook of the National Reading Conference (pp. 357372). Oak Creek, WI: National Reading Conference

Wright, V.H. \& Wilson, E.K. (2011). Teachers' use of technology: Lessons learned from the teacher education program to the classroom. The Journal of the Southeastern Regional Association of Teacher Educators, 2(2), 48-60. 